\title{
A REFORMA DA PROVÍNCIA FRANCISCANA DA IMACULADA CONCEIÇÃO (1738-1740) (II).
}

\author{
(Continuação) . \\ GENTIL AVELINO TITTON, O. F. M. \\ CAPITULO IV. \\ FORMAÇÃO DO NOVO GOVERNO.
}

Continuando em ordem cronológica, seguem-se várias medidas tomadas pelo Reformador, a fim de realizar o que certamente mais lhe importava, isto é, formar um nôvo govêrno na Província, composto de elementos de sua confiança. Tal programa executou-o Dom Guadalupe gradualmente nos meses seguintes, de setembro de 1738 a janeiro de 1739 .

\section{1. - RENUNCIA DO PROVINCIAL E ANULAÇÃO DAS DEMAIS ELEIÇÕES.}

A 24 de setembro de 1738, apareceu de nôvo Dom Antônio de Guadalupe no Convento de Santo Antônio do Rio de Janeiro. Na biblioteca, em presença do Bispo Reformador e de todos os frades do mesmo convento, levantou-se o Provincial Frei José de Jesus Maria, eleito a 31 de maio do mesmo ano, e declarou que, após governar com o zêlo que podia, renunciava

\footnotetext{
"de sua livre e espontânea vontade" ao cargo, devido ao pêso do mesmo e a "alguns achaques que the sobrevieram";
}

e entregou os selos nas mãos do Reformador, pedindo-lhe que nomeasse quem julgasse melhor para substituí-lo (1). Este aceitou a renúncia e, dizendo que conhecia

(1). - TG. II, f. 47v-48. Era Frei José de Jesus Maria de filiação brasileira. Antes de ser eleito Provincial no Capítulo de 1738, ocupara vários cargos na Província. Por duas vêzes fôra eleito Definidor, em 1710 e em 1735. TG. f. $24 \mathrm{v}$; Estatutos, p. 272. No ano de 1737 fôra superior da aldeia de Santo Antônio dos Guarulhos. 
 \\ “o bom procedimento e zêlo do serviço de Deus"
}

do Provincial renunciante durante seu govêrno, agraciou-o com o título de Padre da Província com todos os privilégios a êle inerentes, embora não tivesse exercido o cargo por dois anos completos.

Em seguida, afirma o Bispo que

"estava exatamente informado e certificado"

que a eleição passada de Custódio e dos quatro Definidores fôra realizada

\author{
"contra as Constituições Apostólicas, tanto pela indignidade dos \\ sujeitos, como pelo subôrno com que fôra executada"
}

e por isso a declarava nula (2). Por êste ato depunha o Reformador ao Custódio Frei Caetano da Purificação (3), e aos quatro Definidores Frei Constantino de Santa Maria (4), Frei Antônio Batista (5), Frei José de Santa Teresa e Frei Inácio de São Boaventura (6).

Foi realmente espontânea a renúncia do Provincial? Cremos que não. E' inverossimil que Dom Guadalupe, tendo declarado inválida a eleição do Custódio e dos quatro Definidores por julgá-la realizada contra as Constituições Apostólicas e com subôrno, considerasse válida a eleição do Provincial. E a alegação dos achaques que teriam atacado o Provincial renunciante, sobrevindos nos dois meses de govêrno, não convence. Evidentemente o Reformador queria um nôvo

(2). - TG II, f. 48. O Capítulo de 1738 fôra realizado no Convento do Bom Jesus da Ilha, como o de 1735, para evitar distúrbios e para maior sossêgo e liberdade. Isso revela que existiam ainda, latentes, muitas rivalidades entre os dois partidos. Dera-se também dispensa aos do partido do Brasil, por falta de "sujeitos qualificados". TG II, f. $41 \mathrm{v}-42$.

(3). - Frei Caetano devia pertencer ao partido de Portugal, pois o Provincial Frei José de Jesus Maria era brasileiro. Tinha sido eleito guardião do Convento de Santo Antônio do Rio de Janeiro a 12 de fevereiro de 1735 , ao ser o guardião de então promovido a Custódio. TG II, f. $22 \mathrm{v}$.

(4). - De Frei Constantino sabe-se que era brasileiro. Fôra escolhido para superior da aldeia de São Miguel no capítulo de 1723. AHU, Rio de Janeiro, n. 4484. E o Capítulo de 1732 , tão pródigo $\mathrm{em}$ conceder privilégios, agraciou-o com o título de Ex-definidor "em atenção aos seus serviços e outras ocupações" em prol da Província. TG. II, f, $15 \mathrm{v}$.

(5). - De Frei Antônio Batista sabemos apenas que o Capítulo de 1723 o escolhera para guardião do Convento de Cabo Frio e que pertencia ao partido de Portugal. AHU, Rio de Janeiro, n. 4484.

(6). - Não consta a que filiação pertenciam êstes dois Definidores, mas pela lógica da Alternativa, um devia ser brasileiro e o outro português. Frei Inácio de São Boaventura exerceu o cargo de Comissário Visitador da Fraternidade da Ordem Terceira de São Paulo em 1726. ORTMANN (Adalberto), História da Antiga Capela da Ordem Terceira da Penitência de São Francisco em São Paulo. Publicações do DPHAN, n. 16, Rio de Janeiro, 1951, p. 422. 
Provincial nomeado por êle. Talvez tenha pedido a Frei José que renunciasse e êste tenha aquiescido. Possivelmente terá simplesmente exigido a renúncia. O autor do Resumo do Tombo afirma sem mais que o Bispo

"começou o exercício de sua autoridade por exigir que o Provincial, Custódio e Definidores renunciassem" (7).

\section{2. - FORMAÇÃO DO NÔVO GOVERNO.}

Após a renúncia do Provincial Frei José de Jesus Maria e a deposição dos demais membros do Definitório, procedeu Dom Guadalupe à constituição do nôvo govêrno da Província da Imaculada Conceiçção. Realizou-se em dois tempos: a maioria das nomeações fê-las o interventor nessa mesma oportunidade; as outras nomeações, para preencher alguns cargos deixados vagos, fê-las sòmente uns quatro meses mais tarde, pelos meados de janeiro de 1739.

\section{Primeiras Nomeações.}

Imediatamente após a anulação das eleições passadas e da renúncia do Provincial, anunciou Dom Guadalupe aos frades reunidos na biblioteca do convento de Santo Antônio, que nomeava para Provincial a Frei Lucas de São Francisco; para Definidores da filiação brasileira a Frei Antônio da Conceição Godinho e Frei Diogo de Santo Inácio; para Definidor da filiação portuguêsa a Frei Agostinho da Trindade; e que confirmava de nổvo aos guardiães todos dos conventos - exceto os que por suas patentes já se achavam promovidos dos ofícios - a fim de

$$
\text { "tirar todo o escrúpulo que podia haver" }
$$

a respeito de sua eleição no Capítulo passado (8). Faltava o Custódio e um Definidor do partido de Portugal. Quanto a êles, disse o Reformador que já os tinha eleito, mas reservava a publicação dos nomes para mais tarde, porque

$$
\text { "se achavam ao presente ausentes dêste convento"; }
$$

e imediatamente, após absolvição de possíveis impedimentos ou defeitos canônicos, deu posse ao Provincial, entregando-lhe os selos da Província, e aos três Definidores presentes (9).

(7). - RESUMO TG., p. 34. E admira-se o autor do Resumo que êstes tenham renunciado "sem a menor repugnância".

(8). - TG. II, f. $48 \mathrm{v}$.

(9). - TG. II, f. $48 \mathrm{v}$. 
Um conhecimento mais detalhado das pessoas colocadas pelo Reformador nos postos de Provincial, Definidores, etc., ajudará a formar mais tarde um juízo sôbre a atuação de Dom Guadalupe na qualidade de interventor na Província da Imaculada.

Frei Lucas de São Francisco, brasileiro, Definidor no triênio 1713-1716, participara da rebelião de 1723 - à qual brevemente nos referimos - em que um grupo de frades capitaneados por Frei Tomás das Neves não aceitara o Visitador enviado pelo Ministro Geral e, reunidos no Convento do Bom Jesus da Ilha, realizaram seu próprio Capítulo com eleição de Provincial, Custódio, Definidores e guardiães para todos os conventos. Neste pseudo-capítulo, os dissidentes escolheram a Frei Lucas como Provincial e êle aceitou. Há documentos que o apontam como um dos cabeças dos frades dissidentes (10). Em 1725, Frei Lucas submeteu-se à obediência ao superior legitimamente eleito, mas nos anos seguintes não deixou de agir para conseguir galgar os mais altos cargos que ambicionava (11). Aos 12 de novembro de 1732, o Definitório apresentou-o em primeiro lugar na terna enviada ao Ministro Geral para êste nomear o próximo Visitador da Província, mas o Geral recusou-o como incapaz e por ter sido

$$
\text { "cabeça e chefe das passadas revoluções" (12). }
$$

A êste frade colocou Dom Guadalupe no pôsto de Provincial, para o triênio em que êle agiria como interventor.

Quanto aos Definidores de filiação brasiliense: Frei Antônio da Conceição Godinho fôra também um dos cabeças da dissidência de 1723. Exercera várias vêzes o cargo de guardião: em 1735 fôra eleito guardião do Convento de Santo Antônio do Rio, casa do Provincialado, mas não foi confirmado em 1736 (13). Em 1742 estará ocupando a guardiania no Convento do Bom Jesus da Ilha (14) e em 1743 é novamente escolhido para guardião do Santo Antônio

(10). - AHU, Rio de Janeiro, n. 4463 e 4465.

(11). - ORTMANN, Subsidios, em Vita Franciscana 7, (1930), p. 8-10.

(12). - A princípio o Ministro Geral, estando em Sevilha, o aprovara. Mas, voltando a Madrid, foi informado sôbre a pessoa de Frei Lucas e dos outros dois da terna. Magoado, não só revogou a patente já expedida, mas ainda enviou repreensão ao Definitório. TG. II, f. 16 e 22 Cf. ROEWER, História, p. 77. Não faltavam, porém, a Frei Lucas talento e boas qualidades. Em 1727, desgostado de certo com as vicissitudes do cisma provincial, pedira êle para passar a uma das outras Ordens Mendicantes, o que não chegou a realizar. Nessa ocasião, o procurador dos Recoletos e Descalços afirma ser uma pena que "um tal sujeito, idoso e de valor, queira abandonar seu povo". AGOFM, II/8, Parte II, p. 115.

(13). - TG. II, f. 21; Cf. ROEWER, Historia, p. 86.

(14). - TG. II, f. $62 \mathrm{v}$. 
do Rio de Janeiro (15). Fôra também Lente de Teologia e Definidor provincial, e por fim saiu eleito Ministro Provincial no capítulo de 1745 , sendo o quarto de filiação brasileira após a introdução da Alternativa na Província (16).

O outro Definidor brasileiro, Frei Diogo de Santo Inácio, exercera o cargo de Comissário da Ordem Terceira de São Paulo por mais de 9 anos e fôra Leitor de Teologia (17). Morreu em fins de 1741, pois o Visitador, antes de celebrar o capítulo de janeiro de 1742, nomeia um Definidor subrogado para ocupar a vaga aberta com a morte de Frei Diogo (18).

O Definidor de filiação portuguêsa, Frei Agostinho da Trindade Seixas, era natural do bispado de Lamego, em Portugal. Sendo já formado em Gramática Latina e Letras Humanas passou ao Brasil e veio morar no Rio de Janeiro com seu irmão Francisco de Seixas da Fonseca. Continuou ali os estudos e vestiu o hábito de São Francisco no Convento de Santo Antônio. Tinha talento para a poesia, tanto latina, como portuguêsa, deixando alguns poemas em louvor do Definidor Geral Frei Fernando de Santo Antônio (19). Ocupara também o cargo de Definidor de 1719 a 1723.

Também Frei Agostinho da Trindade participara dos acontecimentos de 1723-1725, como um dos chefes do grupo dissidente. Quando em 1722, por falta de Visitador nomeado pelo Geral, o Definitório provincial elegeu a Frei Tomás das Neves, êste encarregou-se de visitar os conventos da parte sul da Província e delegou ao Definidor Frei Agostinho da Trindade para percorrer os conventos da parte norte. Tendo, porém, o Ministro Geral nomeado seu Visitador, também Frei Agostinho não o reconheceu; uniu-se a Frei Tomás das Neves e aos demais que, reunidos no Convento do Bom Jesus da Ilha, realizaram Capítulo à parte. Frei Agostinho com alguns dissidentes procuraram amotinar os seculares e conquistá-los para sua causa. Para isso foram à Cidade e espalharam um manifesto entre

\footnotetext{
(19). - BARBOSA MACHADO, Bibliotheca Lusitana, t. I, p. 75. Afirma êste autor que Frei Agostinho foi também guardião duas vêzes. Uma vez, será êle nomeado guardião do Convento de Santo Antônio do Rio, a 14 de janeiro de 1739, pelo próprio Dom Antônio de Guadalupe, para o que renunciou ao cargo de Definidor, como veremos ainda. Não se sabe quando ocupou a guardiania pela outra vez.
} atas.

(15). - RESUMO TG., p. 40.

(16). - ROEWER, História, p. 100ss.

(17). - TG. II, f. 23v.

(18). - TG. II, f. 60v. Poucos meses antes, Frei Diogo ainda assinara as 
o povo (20). Frei Agostinho teve sucesso junto aos irmãos da Ordem Terceira Franciscana do Rio de Janeiro, cujo Ministro era seu próprio irmão Francisco de Seixas da Fonseca, homem muito rico e por sua vez empenhado em obter para sua irmandade maior independência diante dos superiores da Província, à qual a irmandade estava sujeita (21).

Quanto aos guardiães dos conventos, dissemos que o Reformador, para evitar possíveis dúvidas, confirmou a todos os que tinham sido eleitos no Capítulo passado de 31 de maio,

\footnotetext{
"exceto aquêles que por suas letras patentes se acham já promovidos dos Ofícios".
}

Não consta no Livro do Tombo que algum dos guardiães tivesse sido "promovido do Ofício". O único que não foi confirmado no pôsto foi o guardião do Convento de Santo Antônio do Rio de Janeiro, Frei Domingos do Rosário, que não foi promovido, mas "privado" do cargo (22).

O pôsto de guardião do Convento de Santo Antônio do Rio de Janeiro ficou vago até 14 de janeiro de 1739, quando o Reformador nomeou para êle a Frei Agostinho da Trindade, como veremos.

Não consta qual o motivo por que Frei Domingos foi deposto do cargo de guardião do Convento de Santo Antônio. Certamente não por ser êle o único indigno dentre os treze guardiães então existentes, mas simplesmente porque o Reformador desejava colocar no pôsto de guardião do convento maior e mais importante, sede do Provincialado, a um religioso de sua inteira confiança.

Notam-se algumas incongruências no procedimento de Dom Guadalupe. Quanto ao Provincial, deu-se a renúncia, que provàvelmente foi exigida pelo Reformador. Quanto ao Custódio e aos 4 Definidores, declara nula a eleição

(20). - AHU, Rio de Janeiro, n. 4466. Um dos frades que com Frei Agostinho tentou sublevar o povo era Frei Bernardino de Jesus. AHU, Rio de Janeiro, n. 4453 .

(21). - AHU, Rio de Janeiro, n. 4492.

(22). - TG. II, f. 50. Frei Domingos fôra agraciado no Capítulo de 1732 com o título de Ex-definidor, em atenção aos serviços até ali prestados: fôra guardião várias vêzes e na ocasião dirigia as obras da escola do Convento de São Boaventura de Macacu. TG. II, f. 14. Elegeram-no Definidor em 1735. Em junho de 1738, pouco antes de o interventor tomar posse, o Definitório o propusera em terceiro lugar na terna enviada ao Ministro Geral, para a nomeação do próximo Visitador da Província. TG. II, f. 44. Por fím, vários anos após a intervenção apostólica, exerceu o cargo de Visitador e Presidente do Capítulo provincial de 1748. 
"tanto pela indignidade dos sugeitos, como pelo subôrno com que fôra executada",

e afirma que estava

"exatamente informado e certificado"

disso. Quanto aos guardiães, para evitar possíveis dúvidas, confirma-os todos, exceto o do Santo Antônio do Rio de Janeiro. Ora, é inverossímil que só o Custódio e os quatro Definidores tenham sido eleitos invàlidamente por serem indignos e pelo subôrno usado, enquanto que todos os guardiães - menos um - foram considerados dignos de confirmação no ofício. O fato de o Reformador confirmá-los ad cautelam mostra que não estava muito convencido da nulidade da eleição. E o fato de só ter privado do ofício a um dêles revela que não os considerava tão indignos e que o Capítulo passado de 1738 não fôra tão negligente na escôlha dos sugeitos, como o Reformador afirmava.

Igualmente a eleição do Provincial não fôra tão má, pois o próprio Dom Guadalupe lhe louva o

"zêlo e bom procedimento"

e além disso lhe confere o título de Padre da Província.

Nomeações Posteriores.

Voltemos à formação dos quadros de govêrno da Província. Como vimos, a 24 de setembro o Reformador deixou de proclamar os nomes do Custódio e de um Definidor, ambos do partido português, dizendo que tinha eleito os religiosos para êstes dois cargos, mas êles

$$
\text { "se achavam ausentes ao presente dêste convento". }
$$

Faltava igualmente a nomeação de guardião do Convento de Santo Antônio, no lugar do deposto Frei Domingos do Rosário.

Passarem-se quase quatro meses, quando, a 14 de janeiro de 1739, procedeu o Bispo Reformador à prometida publicação dos nomes. Antes dissera simplesmente que adiava a publicação devido à ausência das pessoas já escolhidas por êle; agora afirma que fizera a dita dilação

"por justas causas" e para "ter mais conhecimento dos religiosos que havia de nomear" (23).

(23). - TG. II, f. 50. 
Ora, se já tinha os nomes escolhidos antes, por que diz que queria conhecer melhor as pessoas a serem nomeadas? Ainda não tinha fixado os nomes? Nota-se certa incongruência entre as duas afirmações do Reformador.

Seja qual fôr o motivo verdadeiro da dilação, agora completou êle os quadros do govêrno da Província, com a nomeação de Frei José de São Boaventura para Definidor e o pregador Frei Paulo do Nascimento para Custódio, além de nomear também o guardião do Convento de Santo Antônio na pessoa do Definidor antes por êle nomeado Frei Agostinho da Trindade (24).

Frei José de São Boaventura já exercera o cargo de Definidor provincial em 1726. Era do partido de Portugal e fôra guardião do Convento de Santo Antônio do Rio de Janeiro, eleito em 1723, na ocasião do cisma provincial, confirmado na Congregação Intermédia seguinte. Distinguiu-se como sacro orador (25).

Frei Paulo do Nascimento, o Custódio nomeado, nasceu em Portugal em 1697, veio jovem ao Brasil e aqui empreendeu muitas viagens. Recebeu o hábito na Província da Imaculada no Convento de Vitória a 3 de setembro de 1719. Foi guardião do convento de São Francisco de São Paulo. Poeta, escreveu várias poesias latinas, as quais, porém, se perderam (26) .

O Definitório escolheu-o em 1732, para ser procurador da Província em Lisboa (27). Pouco depois, em 1734, foi criado Comissário do Santo Ofício para a Cidade e Capitania de São Paulo. Frei Paulo pede ao Rei que, ao dirigir-se àquela cidade para assumir o cargo, possa passar pelas Minas Gerais, a fim de ajustar uns negócios contraídos com seus irmãos que lá moravam. O Rei lhe dá a licença pedida (28). Contudo, Frei Paulo do Nascimento não voltou logo para o Brasil, porque o Rei Dom João V o reteve na Côrte (29). Só regressou à Província em 1733, assumindo o cargo de Custódio para o qual o Reformador o escolhera. Na qualidade de Custódio da Província foi de nôvo à Europa participar do Capítulo geral da Ordem em Valladolid, em 1740, no qual votou (30).

(24). - TG. II, f. 50v.

(25). - AHU, Rio de Janeiro, n. 4484; FREITAS (Diogo de), Elencho Biographico dos Religiosos Antigos da Provincia Franciscana da Immaculada Conceição do Brasil, Petrópolis 1931, n. 115.

(26). - BARBOSA MACHADO, Bibliotheca Lusitana, T. III, pp. 524-525.

(27). - TG. II, f. 16; FREITAS, Elencho, n. 176.

(28). - AHU, Rio de Janeiro, n. 9014. Estamos no ano de 1735.

(29). - Em carta régia de 22 de março de 1736, escreve o Rei ao Definitói io que Frei Paulo com mais alguns outros estava pronto para voltar ao Brasil, mas que mandou "não embarcasse por ora na frota que está próxima a partir". TG. II, f. 26.

(30). - BARBOSA MACHADO, Bibliotheca Lusitana, t. III, p. 525. 
Com a nomeação do Definidor Frei Agostinho da Trindade para guardião do Convento de Santo Antônio do Rio de Janeiro, criou-se incompatibilidade de cargos, segundo os Estatutos da Província (31). Não podia Frei Agostinho ocupar o pôsto de Definidor e guardião ao mesmo tempo.

Mas Dom Guadalupe tinha seus planos. Pediu a Frei Agostinho para desistir do cargo de Definidor, para ocupar o de guardião. Pediu-lhe que o fizesse em sua presença e com a maior brevidade possível, pois estava com pressa de nomear o Definidor subrogado. Frei Agostinho não perdeu tempo, dirigiu-se logo no dia seguinte à presença do Bispo, diante do qua! renunciou ao cargo de Definidor, e

"humildemente aceitou a ocupação de guardião do sobredito Convento de Santo Antônio, sugeitando-se com reverente submissão ao trabalho da Religião".

E para ocupar o cargo de Definidor, tornado vago pela renúncia acima, na mesma hora Dom Guadalupe

"elegeu e declarou por Definidor legitimamente subrogado ao R. P. M. Frei Francisco das Chagas por ser (segundo a Alternativa) o Padre da Província suficientemente habilitado, a que pertence a sobredita subrogação" (32).

Era por isso que Dom Guadalupe adiara a publicação dos nomes. Queria esperar a volta de Frei Francisco das Chagas de Portugal, reservando-lhe um pôsto importante na Província da Imaculada Conceição.

Já consideramos acima como Frei Francisco das Chagas, tendo alcançado do Papa o Breve de convalidação de sua incorporação à Província, enviou-o à mesa definitorial junto com uma carta régia que mandava sua execução. E vimos também como o Definitório recusou-se a aceitar tanto o Breve como a carta régia. Ora, pouco antes de nomeá-lo Definidor subrogado, Dom Guadalupe, que ajudara Frei Francisco dando-lhe carta de recomendação ao partir para a Europa, pôs seu "Cumpra-se" ao Breve, aos 9 de dezembro de 1738, e mandou o Provincial com o Definitório aceitá-lo, o que êstes fizeram no dia seguinte (33). Assim estava Frei Francisco incorporado definitivamente à Província da Imaculada Conceição e habilitado para ocupar o cargo a êle reservado pelo Reformador. E não parou aí a carreira de Frei Francisco das Chagas na Província da Imaculada.

(31). - Estatutos, p. 107.

(32). - TG. II, f. 50v.

(33). - TG. II, f. 50. 
Logo no primeiro capítulo celebrado após a intervenção apostólica, ei-lo escolhido Provincial para o triénio 1742-1745, cargo que desempenhou assás louvàvelmente (34) .

Outra nomeação realizada pelo Bispo Reformador, antes de ser obrigado a interromper sua reforma por ter sido transferido para a diocese de Viseu, é a eleição de guardião para o Convento de Santo Antônio do Rio de Janeiro, realizada no fim do ano, a 15 de dezembro de 1739 , na Congregação intermédia. O Livro do Tombo apenas refere que a Congregação intermédia foi a última operação do Reformador, antes de partir de volta a Portugal; não menciona nada do que nela se fêz (35). E' o autor de Resumo do Tombo quem dá a informação que nessa Congregação intermédia foi eleito Frei João da Conceição para guardião do Convento de Santo Antônio do Rio de Janeiro (36).

Já dissemos que Frei João da Conceição fôra escolhido por Dom Guadalupe para Secretário da Visita e Reforma. Tinha sido por dois anos Lente de Teologia no mesmo Convento de Santo Antônio. No Congresso capitular de 1738 , pouco antes de começar a intervenção de Dom Guadalupe, fôra escolhido pelo Definitório para ser Lente de Moral e Casos de Conciência no mesmo convento, para ensinar aos Religiosos

$$
\text { "as regras, questōes e opiniōes mais firmes e sólidas" (37). }
$$

Foi ainda Frei João consultor do bispado, Custódio em 1748; e em 1751 exercia o munus de Missionário Apostólico no norte da Província (38).

Não se tem notícias de outras nomeações efetuadas pelo interventor Dom Antônio de Guadalupe, a não ser as nomeações para Padres Lentes, nas providências que tomou em relação aos estudos na Província, o que analisaremos mais adiante.

(34) . - ROEWER, História, p. 97-99.

(35). - TG. II, f. 58. Por que não foi confirmado Frei Agostinho da Trindade, colocado no cargo pelo Reformador em janeiro dêsse mesmo ano? Os documentos não elucidam êste particular. O fato é extranho, pois Frei Agostinho era homem de confiança de Dom Guadalupe, como se nota pelos têrmos elogiosos a seu respeito, usados pelo 'Bispo ao nomeá-lo guardião. Dissera Dom Guadalupe que o nomeava por ser "muito conveniente ao serviço de Deus e promoção da reforma, pelo bom conceito que tem da sua religiosidade e inteireza e de que fará observar exatamente a Santa Regra...". TG. II, f. 50v.

(36). - RESUMO TG., p. 37.

(37). - TG. II, f. 43. Pouco antes fôra designado Lente de Filosofia, mas não chegou a lecionar, por ter sido nomeado para a cadeira de Moral. O mesmo Definitório manda que os superiores obriguem os religiosos seus súditos a levar-lhe dúvidas, "para que êste as solte com clareza com o fruto que esperamos". Ibid.

(38). - FREITAS, Elencho, n. 188. 


\section{CAPITULO V. \\ PUNIÇÃO DE FREI JOSE DO NASCIMENTO E FREI MANUEL $D A$ ENCARNAÇAOO.}

Pouco depois da nomeação do nôvo Provincial e de três Definidores (24-9-1738) e antes da de Custódio e do outro Definidor (14-1-1739), tomou o Reformador algumas medidas de que nos ocuparemos neste capítulo. Representam um episódio doloroso da sua intervenção apostólica na Província.

Já nos referimos acima, ao expor as relações entre Dom Guadalupe e os franciscanos da Província da Imaculada, à desinteligência havida em 1735 entre o Bispo e o então Provincial Frei José do Nascimento. Por não ter êste castigado a um religioso acusado de irregularidades, fulminou o Bispo do Rio de Janeiro sentença contra Frei José, declarando-o destituído do cargo. Frei José interpusera recurso à Corôa . O processo, como era natural devido às circunstâncias do tempo, não se resolveu imediatamente, mas prolongou-se pelos anos seguintes.

Para preparar o recurso à Corôa, o Provincial mandou o Lente Frei Manuel da Encarnação elaborar um parecer sôbre a jurisdição dos Bispos em semelhantes casos (1).

Agora, revestido dos podêres especiais concedidos pelo Breve para a reforma da Província, não se conteve infelizmente Dom Antônio de Guadalupe. Praticou ato de vingança contra seus dois adversários: prendeu o então Ex-provincial Frei José no cárcere do Convento de Santo Antônio do Rio de Janeiro e depôs da cátedra o Lente Frei Manuel.

(1). - TG. II, f. $29 \mathrm{v}-31 \mathrm{v}$. É o texto do Parecer. Os argumentos bem elaborados, mostrando que o Bispo do Rio de Janeiro não tinha jurisdição no caso mencionado, ajudaram certamente a dar ganho de causa ao Provincial. 
Não constam nem o dia, nem o mês destas medidas, pois o Reformador agiu por ato particular (2). Mas devem ter sido tomadas antes do fim de 1738 (3).

\section{1. - ENCARCERAMENTO DE FREI JOSE DO NASCI- MENTO.}

Frei José do Nascimento, Ministro Provincial durante o triênio de 1735-1738, era de filiação portuguêsa e exercera antes disto vários cargos na Província (4). Não chegou a realizar obras extraordinárias no seu triênio; realizou, contudo, um govêrno bom (5) .

No litígio surgido em 1735 portara-se o Bispo do Rio de Janeiro com demasiada severidade, pelo que o Provincial recorreu da sentença e abriu processo contra o Prelado. Sendo Interventor na Província, não poupou Dom Antônio de Guadalupe seu adversário, como dissemos. Mandou prendê-lo no cárcere do Convento de Santo Antônio do Rio de Janeiro.

Frei José permaneceu no cárcere pouco tempo, alguns meses dpenas. Pelos meados de janeiro de 1739 conseguiu, com auxílio de pessoas de fora, evadir-se do cárcere.

(2). - Aliás, nada do litígio que contrapôs o Bispo do Rio de Janeiro a Frei José do Nascimento e Frei Manuel da Encarnação constava no antigo Arquivo da Província, que o autor do Tombo Geral transcreve fielmente. Dí-lo expressamente o autor Frei José do Destêrro - que começou sua obra em 1782 - afirmando que conseguiu "por diligências muitas" informar-se do acontecido e apoderar-se dos documentos relativos ao caso. "Para de todo não se consumir com o tempo" a lembrança do sucedido, resolveu êle historiar brevemente os fatos e transcrever os documentos que conseguira arranjar. TG. II, f. 29.

(3). - A autor do Tombo Geral afirma a certa altura (TG. II, f. 53) que o encarceramento foi efetuado "pouco depois de [Dom Guadalupe] tomar posse de Reformador", o que se dera a 2 de agôsto de 1738. Em outra passagem (TG. II, f. $50 \mathrm{v}$ ) diz o mesmo autor que o encarceramento do Ex-provincial e a deposição de Frei Manuel foram "logo depois da nomeação do nôvo Provincial" - o que se verificara a 24 de setembro - mas antes da Lei Escolástica de 10 de novembro de 1738.

(4). - No tumultuado Capítulo provincial de 1723 fôra escolhido para guardião do Convento de Santo Antônio de Santos. AHU, Rio de Janeiro, n. 4484. Em 1726 fôra nomeado comissário da Ordem Terceira do Rio de Janeiro. Exerceu também o ofício de Notário Apostólico no Rio pelos anos de 1733-1734. No Capítulo de 1732 elegeram-no Definidor da Província e no de 1735 Provincial. FREITAS, Elencho, n. 189.

(5). - Roewer designa-o de "excelente Provincial". História, p. 87. Tomou providências para o fomento dos estudos, mostrou interêsse pela formação dos noviços. No seu govêrno, no ano de 1735, foi confiada à Província da Imaculada a administração temporal e espiritual da aldeia de indios de Nossa Senhora da Escada, perto de Jacaré, com a incumbência de os frades missionarem também os indios das circunvizinhanças. ROEWER, Páginas, p. 645. 
Quanto à pena de cárcere infligida a Frei José, não constam mais detalhes. Naquele tempo, tal pena era muito comum entre os Religiosos, não sendo necessárias faltas muito graves para se cair no cárcere. Havia várias modalidades, previstas nos Estatutos da Província (6). A sentença de 1741 contra o Bispo do Rio refere-se vagamente ao "rigor excessivo" usado contra o Ex-provincial ao ser encarcerado (7). Igualmente uma carta do brigadeiro José da Silva Paes ao Governador, dando conta das diligências para prender o fugitivo Frei José, refere-se ao "cárcere rigoroso" donde escapara (8). Porém, o autor do Tombo, Frei José do Destêrro, confessa:

\footnotetext{
"Ignoro se [o Bispo] o obrigou a fazer algumas penitências..." (9)
}

Quem ajudou o Ex-provincial a fugir da prisão do convento? Гambém a êste respeito nada consta. Sabe-se apenas, através do autor do Tombo Gera!, que quem auxiliou na fuga não foram os confrades de Frei José, mas sim pessoas "de fora" (10). Frei José dirigiu-se ao mosteiro dos Beneditinos, mas como os monges quisessem que se apresentasse ao Bispo do Rio de Janeiro, o Ex-provincial sentiu-se inseguro e fugiu dali também. Evidentemente não iria apresentar-se diante de seu encarcerador. E tinha razão... Pois Dom Guadalupe, ao ouvir que Frei José se refugiara junto aos Beneditinos, mandou tropas para cercar o mosteiro e prender o fugitivo, não o conseguindo porém (11).

Mais tarde - em data também ignorada - conseguiu Frei José embarcar para a Côrte de Lisboa, escapando assim dos seus adversários e podendo defender-se pessoalmente perante o Tribunal da Legacia. De lá, recorreu também ao Ministro Geral dos Franciscanos, para que o absolvesse de possíveis censuras incorridas pela sua fuga (12).

Os motivos invocados por Dom Guadalupe para encarcerar a Frei José foram as contas de receita e despesa de seu triênio no govêrno da Província. Seus adversários pretenderam arguir essas contas de

(6). - Havia cárcere perpétuo ou tcmporário; para certos delitos a duração era prevista, para outros ficava ao arbítrio do Prelado; podia ser reclusão simples, ou acompanhada de outras penas. Cf. Estatutos, p. 217-220.

(7). - TG. II, f. 54.

(8). - Arquivo Público Nacional (APN), cod. 84, vol. 9, f. 198.

(9). - TG. II, f. 53.

(10). - TG. II, f. 53.

(11). - APN, cod. 84, vol. 9, f. 198-199.

(12). - TG. II, f. 53v. 
"menos legais e verdadeiras",

como se afirma na sentença de 1741 (13). Contudo, as contas foram apenas pretexto. O motivo real foi o desêjo de vingança do Bispo e do grupo de frades inimigos do ex-provincial Frei José. As contas apresentadas por Frei José ao término de seu mandato tinham sido aprovadas pelo Capítulo provincial e, mais tarde, também pelo Ministro Geral da Ordem.

Durante todos êstes acontecimentos, desenrolava-se em Lisboa o processo iniciado em 1735 por Frei José do Nascimento, àquela altura Ministro Provincial, contra o Bispo do Rio de Janeiro que o declarara deposto do ofício. O processo resultou inteiramente favorável a Frei José. Pronunciou o Tribunal da Legacia a primeira sentença a 9 de dezembro de 1739 . Nela mostra o juiz que o então Provincial não tinha culpa no incidente de 1735 e que o Bispo Dom Antônio de Guadalupe não possuía jurisdição para depôr um superior religioso; e usa de palavras duras com referência ao Bispo do Rio de Janeiro (14).

Uma segunda sentença é pronunciada pelo mesmo Tribunal da Legacia a 6 de março de 1741, também esta favorável a Frei José e contendo palavras duras contra Dom Antônio de Guadalupe (15). Este, porém, já não estava entre os vivos, pois morreu em Lisboa a 31 de agôsto de 1740, poucos dias após voltar a Portugal para tomar posse da diocese de Viseu, para a qual tinha sido transferido. Foi-lhe, portanto, poupado o desgôsto de ler tais expressões a êle dirigidas pelo juiz.

O Bispo do Rio de Janeiro era realmente precipitado e inflexível. Durante o processo, enviaram-se várias vêzes de Lisboa as compulsórias para que o Bispo respondesse, formulando as culpas que êle achava em Frei José. Mas Dom Guadalupe nunca respondeu; antes, chegou a prender o clérigo que levava uma compulsória ao $\mathrm{Mi}$ nistro Provincial dos Franciscanos, para que também êste, da parte da Província, formulasse culpas - se as houvesse - contra o mencionado Frei José do Nascimento (16).

(13). - TG. II, f. 53v.

(14). - Afirma o Tribunal que Dom Guadalupe se portara com "excessos incivis" e que a sentença do Bispo contra Frei José do Nascimento fôra "injusta, acelerada e precipitante, negando-se com escândalo ao apelante a sua natural defesa". TG. II, f. 40.

(15). - Algumas das expressões usadas nesta sentença: Frei José sofrera "violência e ódio de seus contrários"; "fôra notório no Rio de Janeiro a paixão com que se portara contra êle o Excelentíssimo e Reverendíssimo Bispo Visitador e Reformador"; "paixão e má vontade de seus contrários e do Excelentíssimo...". TG. II, f. $53 \mathrm{v}$.

(16). - TG. II, f. 53v. 
Terminada esta triste contenda, apesar das duas sentenças a êle favoráveis, que os restituiam a todos os graus, isenções e preeminências na sua Província, não voltou Frei José ao Brasil.

"Receando nova perseguição dos seus contrários que eram os que com o Illustríssimo Reformador dominavam a Província"

- relata o autor do Tombo - preferiu permanecer em Lisboa, no hospício que a Província lá possuia e que servia de residência aos procuradores na côrte. Lá faleceu dez anos mais tarde, em 1751, confortado com os santos sacramentos,

"indo descansar... dos grandes trabalhos que sofreu por defender os direitos e privilégios da Religião" (17).

\section{2. - DEPOSIÇÃO DE FREI MANUEL DA ENCARNAÇÃO.}

O outro ato arbitrário praticado por Dom Antônio de Guadalupe foi a deposição do Lente Frei Manuel da Encarnação da cadeira de Filosofia que ocupava em 1738 no Convento do Bom Jesus da Ilha. Como o encarceramento de Frei José do Nascimento, também a deposição de Frei Manuel foi realizada por ato particular, do qual não consta a data. Deve ter sido, porém, antes da publicação da Lei Escolástica, isto é, antes do dia 10 de novembro de 1738 (18).

Frei Manuel da Encarnação era então um dos frades mais ilustres da Província (19). Dotado de notável talento poético, compusera vários poemas em latim e em português $(20)$. Orador sacro fecundo e aplaudido, estava - afirma êle ao Definitório ao pedir uma graça em 1738 -

(17). - TG. II, f. 54 .

(18). - TG. II, f. 51 .

(19). - Nasceu Frei Manuel em Portugal. Estudou Filosofia em Lisboa e só depois transferiu-se para o Brasil, onde vestiu o hábito franciscano no Convento de Santo Antônio do Rio de Janeiro, a 7 de dezembro de 1719. Pelos anos de 1730 ensinava Filosofia no Convento de São Francisco em São Paulo. Em seguida ensinou aí Teologia. Destacou-se como Leitòr de talento, "saindo de seu magistério excelentes discípulos". BARBOSA MACHADO, Bibliotheca Lusitana, t. III, p. 249.

(20). - O escritor Frei Apolinário da Conceição, escrevendo em 1732 portanto quando Frei Manuel era ainda jovem e apenas começara sua atividade no magistério - refere que êle compusera poemas épicos em honra de personagens importantes, como o Definidor Geral Frei Fernando de Santo Antônio, filho da mesma Província, dos Governadores de Minas Gerais, São Paulo e Rio de Janeiro, uma elegia latina ao Bispo de Angola enfêrmo, outras elegias, vários sonetos, décimas, canções e diversos sermões. E afirma: “... estas suas obras, que são aplaudidas dos doutos, mereciam a luz da estampa, de que se formariam dois grandes volumes". Primazia, p. 92-93. 


\footnotetext{
"a todo tempo pronto para pregar todos os sermōes de empenho nas maiores necessidades" (21).
}

Sua carreira no magistério constitui também algo de notável: além de Lente de Filosofia e Teologia no Convento de São Francisco na cidade de São Paulo, lecionou Gramática para os coristas no Convento de São Boaventura de Macacu e no de Nossa Senhora dos Anjos' de Cabo Frio (22). E ensinava Filosofia aos coristas do Colégio Bom Jesus da Ilha, em 1738, quando o atingiu a sentença do Reformador Dom Antônio de Guadalupe, que o privava da cátedra que ocupava.

A inimizade entre o Bispo do Rio de Janeiro e Frei Manuel originara-se em 1735, ao começar o litígio entre o mesmo Bispo e o então Provincial Frei José do Nascimento. A pedido do Provincial, elaborou Frei Manuel - que também era entendido em Direito o douto Parecer sôbre a jurisdição dos Bispos. Tal Parecer, com os argumentos bem elaborados, mostrando que o bispo não tinha poder de depor um Superior religioso, certamente contribuiu para dar ao Provincial ganho de causa no processo contra o Bispo Dom Guadalupe.

Quanto a Frei Manuel da Encarnação, não consta mais que sua deposição da cadeira de Filosofia do Convento do Bom Jesus da Ilha. Certamente não foi encarcerado como Frei José, pois do contrário o fato teria sido associado com o do Ex-provincial, e Frei José do Destêrro sem dúvida teria encontrado vestígios e tê-los-ia conservado no Livro do Tombo. Decerto continuou Frei Manuel sua vida comum de frade, sua atividade incansável de pregador, como exercera até então.

A Frei Manuel da Encarnação estava ainda reservado um grande papel na Província da Imaculada Conceição. Exerceu o cargo de Definidor provincial: Em 1757, saiu eleito guardião do Convento de Santo Antônio do Rio de Janeiro, sede do provincialado; e no ano seguinte assumiu o cargo de comissário da Ordem Terceira daquele convento.

Afinal, mais de vinte anos após os tristes fatos ocorridos durante a intervenção de Dom Guadalupe, será Frei Manuel da Encarnação chamado a ocupar o cargo de Ministro Provincial para o triênio de 1761-1764. Tornou-se benemérito pela promoção da disciplina, in-

(21). - TG. II, f. 43v; Cf. FREITAS, Elencho, n. 285. Dos seus sermöes saiu impresso um em 1749, pregado por ocasião das solenidades com que os homens pardos do Rio de Janeiro festejaram o beato Gonçalo Garcia.

(22). - TG. II, f. $43 \mathrm{v}$. 
cremento dos estudos, aumento do número dos religiosos (24). O provincialado de Frei Manuel constituiu um dos mais profícuos governos de que há memória na História da Província da Imaculada Conceição.

(24). - ROEWER, História, p. 119-124; FREITAS, Elencho, n. 285. No seu triênio foram aceitos 88 noviços, número recorde. Estes anos e os seguintes constituem o auge também das atividades de missão, cura d'almas, pregação. 


\section{CAPITULO VI. \\ PROVIDENCIAS PARA OS ESTUDOS.}

Pouco depois da ação contra Frei José do Nascimento e Frei Manuel da Encarnação, ainda antes do fim do ano de 1738, volta Dom Guadalupe sua atenção para o setor dos estudos. Promulga dois documentos a respeito: a Lei Escolástica de 10 de novembro para o estudo de Filosofia no Convento do Bom Jesus da Ilha e a Providência de 4 de dezembro para a manutenção dos cursos de Filosofia e Teologia no mesmo convento. Como no capítulo primeiro não tratamos dos estudos, daremos primeiro uma rápida visão dos Estudos na Província da Imaculada Conceição para, em seguida, abordarmos a atuação do Reformador.

1. - OS ESTUDOS NA PROVINCIA DA IMACULADA.

a). - Acenos Históricos: inícios, desenvolvimento, casas de estudos.

Os primeiros estudos entre os franciscanos no Brasil foram abertos no convento de Olinda em 1596, onze anos após a fundação da primeira Custódia franciscana em terras de Santa Cruz. Desde a invasão holandesa, ou seja, a partir de 1624 , quando boa parte do Nordeste brasileiro caiu nas mãos dos holandeses, tais estudos passaram a funcionar no Convento de São Francisco na Bahia (1).

Em 1650, o Custódio Frei Sebastião do Espírito Santo abriu estudos, também na parte sul da Custódia, no Convento de Santo Antônio do Rio de Janeiro, que se tornaria a casa-mãe da futura Custódia e, a seguir, Província da Imaculada Conceição. Tratava-se de um curso de Filosofia e um de Teologia, aos quais deu por Lentes a Frei Manuel de Cristo e Frei Gregório de São Julião respectivamente (2). Era a época da rápida expansão dos frades de São Francisco pelo sul do país. Talvez o inteligente Custódio previa maior prospe-

(1). - Jaboatão, Novo Orbe Serafico, Parte I, vol. 1, p. 341.

(2). - JABOATÃo, Novo Orbe Serafico, Parte I, vol. 1, p. 341. 
ridade e a independência dos conventos sulinos da Custódia do Norte; por isso providenciou-lhes um centro de estudos.

Foi pois o Convento de Santo Antônio do Rio de Janeiro a primeira casa de estudos dos frades no território da Província da Imaculada Conceição. E continuou como centro de estudos também quando os conventos do Sul se constituíram em Custódia e Província, por mais de dois séculos, até o declínio da Província. Uma breve interrupção nos cursos dados neste convento verificou-se entre os anos de 1728-1742, quando o curso de Filosofia e por alguns anos também o de Teologia funcionaram no Colégio do Bom Jesus da Ilha, como veremos logo adiante. Mas mesmo naqueles anos parece ter funcionado sempre no Convento de Santo Antônio, algo do estudo da Teologia (3).

Após a ereção da Província em 1675, funcionaram estudos também em São Paulo. Embora sejam escassas as referências quanto aos primeiros decênios, um manuscrito de 1743 relata:

"Depois da ereção desta Custódia em Província, neste Convento de N. P. S. Francisco da Cidade de São Paulo, se continuaram sempre estudos de Filosofia e Teologia" (4).

Além disso, de uma determinação do Capítulo provincial de 1687 parece poder concluir-se que então, além do Convento de Santo Antônio do Rio de Janeiro, havia outra casa de estudos na Província. Não se vê como conciliar estas referências com o que afirmam os Estatutos, escritos em 1710 e publicados em 1717:

"... determinamos que haja na nossa Província estudo de Filosofia e Teologia especulativa e moral..." e logo em seguida: “... determinamos que seja o dito estudo nar casa de Santo" Antônio do Rio de Janeiro..." (5).

Seja como fôr, em 1717 temos um dado mais preciso: aparece pela primeira vez o nome de um Lente no Convento de São Paulo: Frei Bernardino de Jesus. O cronista da Província Frei Apolinário da Conceição relata em 1730 que há três casas de estudos: Santo Antônio do Rio de Janeiro, São Francisco em São Paulo e Bom Jesus na Ilha (6). Após 1730, abundam os dados referentes aos es-

(3). - Com efeito, ao eleger a Frei João da Conceição para Lente de Moral e Casos de Consciência no Convento de Santo Antônio a 9 de junho de 1738 , o Definitório afirma que êle já exercera ali por dois anos o ensino da Teologia. TG. II, f. 43 .

(4). - Memória sôbre a Fundação do Convento de São Francisco de São

Paulo, 1743 (MS no Arquivo da Província da Imaculada, não catalogado).

(5). - Estatutos, p. 35.

(6). - CONCEIÇÃO, Epitome, \& 27. 
tudos em São Paulo: ocorrem nomes de muitas e célebres figuras que ensinaram ou cursaram os estudos ali; sabe-se que os Lentes de São Paulo - como também os do Rio de Janeiro - eram chamados a lecionar em outras escolas; que também ali alunos seculares e de outras ordens frequientavam as aulas dos frades, etc. (7).

A terceira casa onde funcionaram estudos de Filosofia e Teologia foi o Convento do Senhor Bom Jesus dos Navegantes, geralmente chamado Bom Jesus da Ilha, por estar situado na ilha do Bom Jesus, na Baía da Guanabara. Este convento foi construído especialmente para ser casa de estudos e só casa de estudos, sendo por isso freqüentemente chamado também Colégio Bom Jesus (8). Logo ao ser eleito Provincial em 1726, resolveu o grande fomentador dos estudos Frei Fernando de Santo Antônio ampliar o edifício e a 29 de julho de 1728 pôde o Definitório colocar ali o curso de Filosofia (9). Porém as obras de ampliação não estavam concluídas. Pouco depois concluíram-se e foi colocada ali também a Teologia. Em 1730 escreve o cronista Frei Apolinário a respeito desta casa de estudos e do Provincial:

$$
\begin{aligned}
& \text { "... mandou acrescentar..., cujas obras... estão já completas, } \\
& \text { criando nesta casa nôvo estudo de Artes e Sagrada Teologia" (10). }
\end{aligned}
$$

Foram os três conventos acima mencionados - Santo Antônio do Rio de Janeiro, São Francisco de São Paulo e Bom Jesus da Ilha - as únicas casas da Província da Imaculada, onde funcionaram estudos de Filosofia e Teologia.

Além da Filosofia e Teologia, não havia no comêço outros estudos para os que entravam na Ordem. Os candidatos já deviam ter adquirido instrução suficiente em Humanidades, e sobretudo na língua latina, chamada também Gramática. No noviciado continuava-se um pouco o estudo do latim. Desde 1723 a Província até exigia dos candidatos diploma das escolas régias que tivessem freqüentado. Contudo não se cogitava muito da formação científica e literária dos frades coristas.

Mas a 11 de junho de 1728, o Padre Geral João de Soto manda que nas Províncias sob sua jurisdicção

(7). - ROEWER, Páginas, p. 95-96.

(8). - Foi em 1719 que o Definitório resolveu "que o hospício da tha se acrescentasse para ser convento e casa de estudo". Cf. ROEWER, Páginas, p. 445. Frei Apolinário, ao enumerar os conventos da Província, diz que o da Ilha foi criado em 1721. Claustro, p. 78.

(9). - TG. I, f. 206 .

(10). - CONCEIÇÃO, Epitome, \& 14. 


\begin{abstract}
"se designassem... dois ou três conventos, onde aos jovens religiosos se thes expliquem Gramática e Humanidades, para que, instruídos pelo espaço de ao menos um ano em latinidade e Letras $\mathrm{Hu}$ manas, possam aproveitar melhor na Filosofia e Letras Divinas" (11).
\end{abstract}

Imediatamente o Definitório provincial anuiu, a 29 de julho do mesmo ano, e abriu o Seminário de Gramática no Convento de São Boaventura em Macacu, enviando para lá 12 coristas, que cada ano deviam ser substituídos por outros 12 (12).

Outra casa onde funcionou o Curso de Gramática para coristas foi o Convento de Nossa Senhora dos Anjos, situado em Cabo Frio. Não se sabe quando a Província abriu curso de Gramática ali. Em 1728, logo após a ordem do Ministro Geral, como vimos, a Província achara suficiente o curso do Convento de Macacu.

O Curso de Gramática em Cabo Frio certamente já funcionava antes de 1738, porque Frei Manuel da Encarnação, ao pedir nêsse ano uma graça ao Definitório, alega ter ensinado Gramática, tanto no Convento de São Boaventura, como no de Nossa Senhora dos Anjos (13). E ao fazer a visita canônica do Convento de Cabo Frio em 1739, o Provincial Frei Lucas de São Francisco inculca que se observem também ali as prescrições do Bispo Reformador, que isentara os coristas de todo o serviço braçal para poderem se dedicar melhor ao estudo (14). mática .

Faltam notícias sôbre a evolução posterior dos estudos de Gra-

b). - Organização dos Estudos.

\title{
Gramática.
}

A Gramática consistia no estudo da língua latina. Era designada também com as expressões "Gramática Latina" ou "Latinidade".

A meta a atingir no estudo do latim era um domínio tal da língua, que facilitasse os estudos posteriores e permitisse compreender bem a Missa e o Breviário. Antes de 1728 - data em que a Província instituiu, como já referimos, o Curso de Gramática, de um ano de duração para os simples coristas - não tinham êstes outra instru-

(11). - Documento citado por PAZOS, Los Estudios, p. 23.

(12). - ROEWER, Páginas, p. 174.

(13). - TG. II, f. 43v. Cremos, pois, que se engana Roewer ao dizer que a Gramática foi aberta em Cabo Frio em 1739 pelo Provincial Frei Lucas de São Francisco. Cf. Páginas, p. 398.

(14). - Tombo de Cabo Frio, f. 21v. 
ção científica ou literária (15). Isto não significa, porém, que antes dessa data o estudo do latim fôsse inteiramente negligenciado. Ensinava-se latim também no noviciado. Os Estatutos Provinciais de 1710 , codificando os costumes vigentes já anteriormente, estabelecem para os noviços, além do aprendizado das cerimônias e usos da Província e da Ordem:

" $\mathrm{E}$ depois do exercício espiritual, será obrigado o dito Mestre mandar reger Gramática uns aos outros e construir as lições do Ofício Divino, Epístolas e Evangelhos, com cujo qüotidiano exercício, que durará também uma hora, sem dúvida aproveitarão e conservarão a Gramática que estudaram lá fora, para na Religião poderem melhor continuar os estudos; pois é a Gramática o fundamento e alicerce das mais ciências" (16).

As Humanidades, ou Estudos Humanísticos, abrangiam, além do latim, outras disciplinas cuja função era ampliar a cultura geral do estudante.

\section{Filosofia e Teologia.}

O curso de Filosofia, chamado frequientemente de Artes e às vêzes também de Ciências Naturais, abrangia as seguintes disciplinas: Lógica, Física, Metafísica, Etica e Matemática. O de Teologia dividia-se em Teologia Especulativa, que estudava os dogmas da fé, e Teologia Moral, que consistia em lição de casos (17).

Os cursos de Filosofia e Teologia duravam, cada qual três anos, e, como regra geral, o mesmo Lente acompanhava o grupo dos estudantes durante os seis anos de estudo (18).

A instituição de Lentes competia ao Definitório provincial. Os esco'hidos prestavam exame e, se aprovados, assumiam a cadeira. Quanto aos Lentes de Teologia, no caso de o ofício vagar, o Provincial supria. Para lecionar Teologia só era admitido quem tivesse lecionado Filosofia por três anos, ou ao menos tivesse sido Passante e mestre das reparações, com aprovação dos Lentes (19).

(15). - Os Estatutos Municipais de 1710, ao tratar dos coristas neo-professos, não prevêem nenhum estudo, a não ser o aprendizado na vida espiritual sob a orientação do Mcstre. Estatutos, p. 28-30.

(16). - Estatutos, p. 17.

(17). - ROEWER, Os Estudos, p. 98-99. Os dois primeiros anos - prescreviam os Estatutos - sel iam para a Teologia especulativa e o terceiro para a Moral. Estatutos, p. 45.

(18). - Estatutos, p: 36.

(19). - Estatutos, p. 45. 
Os Lentes deviam ser cercados do máximo respeito. Qualquer ofensa a êles feita por algum Colegial era severamente punida; se a ofensa fôsse grave, expulsava-se imediatamente o Colegial do estudo (20). Os Lentes estavam isentos do Ofício divino em côno, menos das vésperas e matinas das festas de primeira classe. Completados os seis anos de leitorado recebiam títulos e prívilégios.

No ensino deviam os Lentes seguir o pensamento da escola franciscana, mais particularmente da escola escotista, como prescreviam os Estatutos:

\begin{abstract}
"Ditarão a seus discípulos os ditos Lentes de Artes e Teologia em os seus Cursos a doutrina do nosso subtilíssimo Escoto, e a seguirão sempre conforme a interpretação vulgar dos Escotistas, defendendo suas opiniōes com tôda a compostura e modéstia religiosa, e declarando o melhor que lhes fôr possível o seu sentido, como sempre se usou em a nossa Sagrada Religião" (21).
\end{abstract}

As classes realizavam-se das $7 \mathrm{~h}$. às $9,30 \mathrm{~h}$. da manhã e das $2 \mathrm{~h}$. às $4,30 \mathrm{~h}$. da tarde. O Lente ditava a lição por meia hora e depois passava às explicações. Os alunos não possuíam manuais; escreviam e resumiam as lições ditadas pelo Leitor. Três vêzes por semana às têrças, rquintas e sábados - faziam-se as reparações, das $6 \mathrm{~h}$. às 8 h. da tarde. As reparações eram a repetição da matéria ensinada em classe. Quem assistia os estudantes então não era o Lente da respectiva disciplina, mas um outro, chamado "Passante", ou mestre das reparações (22). Tal repetição, dirigida por outra pessoa que não o Lente habitual, ajudava sem dúvida o aprofundamento da matéria.

Devido à sua ocupação nos estudos, tinham os Colegiais horário especial. Para o Ofício das matinas à meia noite, estavam divididos em dois grupos, que se revezavam tôdas as semanas; e de manhã assistiam à missa conventual, ou ajudavam alguma na mesma hore. Nos domingos e festas de primeira e segunda classe, porém, deviam participar de tôdas as Horas do Ofício. Igualmente deviam assistir sempre às missas cantadas e à da Benedicta, isto é, à missa em honra de Nossa Senhora aos sábados (23). Tendo determinado o que os estudantes deviam observar quanto aos exercícios de piedade, estabelecem os Estatutos:

(20). - Estatutos, p. 37.

(21). - Estatutos, p. 45.

(22). - Estatutos, p. 38. Dos Passantes estabelecem os mesmos Estatutos: "... os quais serão obrigados a escrever a postila da classe, para que assim possam explicar melhor a doutrina aos Colegiais e impugná-la com argumentos; e serão obrigadoos a assistir alternativamente ás reparaçôes, como mestres que são delas". Ibidem.

(23). - Estatutos, p. 37. 
“... e fora disto não serão obrigados a coisa alguma que thes possa impedir o exercício das letras, para o que a Religião os tem determinado" (24).

Mas como bons filhos de São Francisco, se lhes inculca a admoestação tão cara ao santo Fundador:

"Admoestamos aos Irmãos Colegiais que o seu principal cuidado seja acompanhar a ciência com a humildade, piedade, santa oração e devoção, cujo espírito não se deve extinguir com algum exercício ou trabalho" (25).

À noite havia também estudo: Os que iam às matinas estudavam até $9 \mathrm{~h}$. da noite e, após o ofício, até às $3 \mathrm{~h}$. da manhã; os outros estudavam até às $10 \mathrm{~h}$. e das $3 \mathrm{~h}$. às $5 \mathrm{~h}$. da manhã (26). Portanto, deviam os estudantes contentar-se com cinco horas de sono por noite.

As férias duravam cêrca de dois meses, de 7 de dezembro até 2 de fevereiro. Não havia classes também desde sábado antes do Domingo de Ramos até Domingo in Albis; e igualmente tôdas as quartas-feiras do ano (27).

Para favorecer o aproveitamento dos Colegiais e despertar o interêsse pelos estudos, costumavam fazer-se as conclusões, em que todos se reuniam e um estudante defendia uma tese, respondendo, após, às perguntas ou objeções de quem quisesse usar da palavra .

Distinguiam-se duas espécies de conclusões: conclusões "na classe", isto é, particulares, na presença do Lente e dos colegas, e conclusões "em público", isto é, na presença de seculares. As conclusões públicas tornaram-se famosas. Era para os estudantes, e para todos, um dia de festa. A assistência era seleta: vinham letrados, membros do clero secular e regular, o Bispo diocesano e mais tarde por vêzes até os vice-reis (28). Como já aludimos, o próprio Dom Antônio de Guadalupe as assistia frequientemente e apreciava sobretudo as conclusões dos cursos de Frei Francisco das Chagas, como o próprio Bispo testemunhou (29).

Eis o que os Estatutos prescreviam a respeito das conclusões:

"Todos os meses terão conclusões na classe uma vez; e para que os Colegiais se apliquem e haja entre êles emulação no aproveita-

(24). - Estatutos, p. 39-40. E não dcixam de estabelecer normas rigorosas para não se ocuparem com outras coisas, insistindo amiúde que seu dever primordial é ocupar o tempo sèriamente no estudo.

(25). - Estatutos, p. 36.

(26). - Estatutos, p. 37-38.

(27). - Estatutos, p. 38.

(28). - ROEWER, O Convento, p. 144; Idem, Os Estudos, p. 105.

(29). - ASV, Secr. Brev., 2884, f. 92. 
mento das letras, vendo que hão de aparecer diante dos religiosos e mais letrados de fora, permitimos que em cada ciência se possam fazer umas conclusões públicas, sem fausto algum nem aparato notado; mas de tal modo que resplandeça em tudo a perfeição e compostura do nosso estado. Encarregamos muito ao irmão guardião faça quanto possível fôr por assistir a tôdas as conclusões, assim para que veja o que cada um dos estudantes aproveita, como por atalhar as demasiadas porfias que de ordinário há e fazer sinal quando the parecer para que se acabe" (30).

\section{Os Estudantes.}

Nem todos os frades, terminados o ano de noviciado, eram imediatamente admitidos aos estudos. Ao contrário, muitos dêles permaneciam simples coristas por longos anos. Não se fazia como hoje, quando todos os frades candidatos ao sacerdócio entram logo nos estudos de Filosofia e Teologia.

$\mathrm{O}$ adiamento dos estudos se dava por dois motivos. Em primeiro lugar, a falta de vocações para irmão leigo no Brasil fêz com que se aproveitassem os jovens frades neo-professos para os serviços domésticos nos conventos e também para cumprir com a obrigação do Ofício divino em côro (31). Em segundo lugar, a própria concepção da vida franciscana vigente na Província da Imaculada Conceição levava a deixar um tanto de lado os estudos. A Província pertencia ao ramo dos Alcantarinos ou Descalços - seguidores do franciscano São Pedro de Alcântara - cujo ideal consistia em chegar à perfeição pela oração, penitência e prática da humildade. Por isso os Alcantarinos, de modo geral, só se interessavam secundàriamente pela vida ativa, pelo apostolado, pela ciência .

Tal mentalidade influenciou também os frades brasileiros, embora aqui nunca se tenha manifestado com rigor. Provam-no os não poucos frades que, no decurso da história da Província, brilharam como professôres, poetas, escritores, pregadores (32). Prova-o igualmente o extraordinário florescimento dos estudos do Convento de Santo Antônio do Rio de Janeiro na segunda metade do século XVIII.

\section{2. - PROVIDENCIAS DE DOM GUADALUPE.}

Já referimos que o Reformador privou a Frei Manuel da Encarnação da cadeira de Filosofia que ocupava no Colégio do Bom Jesus

(30). - Estatutos, p. 38.

(31). - ROEWER, Os Estudos, p. 100.

(32). - Cf. ROEWER, Os Estudos, p. 100; O Convento, p. 46. 
da Ilha. Para substituí-lo mandou vir à Ilha o Mestre de Filosofia de São Paulo, Frei Arcângelo de Santo Antônio Sá (33).

Para substituí-lo na cadeira de Filosofia em São Paulo, passou Dom Guadalupe patente de Leitor a Frei Cosme de Santo Antônio, que ali mesmo servia de Passante no curso de Filosofia (34).

O autor do Livro do Tombo não refere a data destas nomeações, mas é evidente que foram realizadas pouco antes de 10 de novembro, data da Lei Escolástica.

Seguem-se as duas medidas do Reformador relativas aos estudos, as únicas que o Livro do Tombo nos conservou: a Lei Escolástica de 10-11-1738 e a Providência de 4-12-1738.

a). - Lei Escolástica.

A 10 de novembro de 1738 promulgou o Bispo Reformador a Lei Escolástica para os estudos do Colégio do Bom Jesus da Ilha (35). Após frisar o Bispo

"a experiência que temos do pouco fruto $e$ utilidade que a esta Província tem resultado dos seus estudos" -

são expressões típicas das críticas de Dom Guadalupe - passa a dar normas concretas sôbre os pontos seguintes: 1). - horário dos estudos, aulas e exercícios de piedade; 2 ). - conclusões; 3 ). - recreio; 4). - normas para o Prelado. Vejamos mais detalhadamente as determinações desta Lei:

1). - O horário para os estudantes, reduzido a um esquema, fica sendo como segue:

(33). - Era Frei Arcângelo de filiação portuguêsa e, além de Lente de Filosofia e Teologia, exerceu na Província postos relevantes: comissário interino da Ordem Terceira em São Paulo em 1735, comissário do Santo Ofício, Custódio da Província e enfim Ministro Provincial de 1754 a 1757. Cf. ROEWER, História, p. 112; Idem, Páginas, p. 94; FREITAS, Elencho, n. 198.

(34). - Frei Cosme de Santo Antônio era igualmente de filiação portuguêsa e entrara na Ordem em 1726. Além de Filosofia, ensinou também Teologia. Mais tarde, será Lente de Moral em 1745, comissário da Ordem Terceira, guardião do Convento do Bom Jesus da Ilha em 1748 e do de Macacu em 1767, Definidor de 1751-1754, Custódio no triênio de 1770-1773, e por fim Ministro Provincial de 1773-1777. Seu provincialado foi bastante turbulento, mas conseguiu realizar também obras notáveis. Cf. FREITAS, Elencho, n. 311; ROEWER, História, p. 138.

(35). - TG. II, f. 51-52v. O autor do Tombo, Frei José do Destêrro, escreve que a Lei foi dada para o estudo de Filosofia do Colégio da Ilha. Mas deve ser um engano, pois a Lei contém determinações também para o curso de Teologia e Conferências de Moral. 
$4 \mathrm{~h}$ (no inverno d̀s $5 \mathrm{~h}$ ): Levantar; estudo.

$5 \mathrm{~h}$ (no inverno às $6 \mathrm{~h}$ ): Horas Menores; Missa Conventual (para todos os coristas, menos para os que estivessem ajudando ou tinham ajudado alguma missa; pois durante as Horas Menores os sacerdotes já iam celebrar sua missa); Estudo até às classes (mais ou menos por $1 \mathrm{~h}$ ).

$7 \mathrm{~h} \mathrm{(no} \mathrm{inverno} \mathrm{às} 8 \mathrm{~h}$ ): Classes (por $2 \mathrm{~h}$ inteiras); Estudo (por $1 \mathrm{~h}$ ).

$11 \mathrm{~h}$ : Jantar (nos dias solenes e festivos às $10,30 \mathrm{~h}$, se o Prelado quiser).

$2 \mathrm{~h}$ : Classes (por $2 \mathrm{~h}$ inteiras).

$4 \mathrm{~h}$ : Recreio (por $1 \mathrm{~h}$ ).

$5 \mathrm{~h}$ : Vésperas e Completas; Ladainha de Nossa Senhora (aos sábados cantada); Estudo.

$7 \mathrm{~h}$ : Ceia. E imediatamente após: Reparaçōes (em três dias da semana) ou Conferência de Moral (nos outros dias). Isto valia também para as férias, mas sem as conferências de Moral nos dias de primeira classe.

$9 \mathrm{~h}$ : Matinas e Laudes (para todos: Colegiais e Passantes); Quarto de Oração Mental; Disciplina (1 vêz por semana, 3 vêzes na Quaresma); Dormir.

A piedade do Bispo Reformador se revela ao prescrever que a Missa e Vésperas fôssem cantadas nas festas de primeira classe e nas de Nossa Senhora de segunda classe, quando fôssem de guarda; que a Missa conventual se celebrasse sempre no altar de Nossa Senhora,

"para que os Colegiais religiosos se afeiçoem a esta grande devoção e a tomem por Patrona dos seus estudos".

Mostrando que tomava a sério a formação dos estudantes, prescreve Dom Guadalupe que nas horas de classe

"não poderá Prelado algum nem ainda o mesmo Leitor ocupar Colegial em coisa alguma fora da classe" (36).

2). - Quanto às conclusões tão apreciadas naquele tempo, estabelece Dom Guadalupe: Mensalmente haja algumas conclusões "interiores" na classe da tarde e "umas conclusões públicas em cada ciência"; na Lógica, haja sempre duas públicas. No curso de Teologia haja algumas conclusões durante o ano, de cada um dos Lentes (37).

(36). - TG. II, f. 51-51v.

(37). - TG. II, f. 51v. 


\begin{abstract}
"A tôdas as conclusões - determina o Bispo - assistirá o Prelado com o que fôr necessário, para o decente e moderado fausto, segundo o nosso estado, evitando superfluidades, como também pinturas ou artefícios nas conclusōes" (38).
\end{abstract}

Mostrou-se, portanto, o Bispo do Rio de Janeiro mais generoso que os Estatutos da Província, os quais, como vimos, não recomendavam nada, a não ser a moderação devida à condição de pobreza dos seguidores de São Francisco. Dom Guadalupe aconselha ao Superior um pouco de largueza, para abrilhantar a festa das conclusões, embora sem esquecer-se da pobreza, rigorosa sobretudo no ramo dos alcantarinos .

3). - Quanto ao recreio, a disciplina entre os frades estudantes era realmente severa e o Reformador não a mitiga. Permite-lhes passear à horta ou até à praia nos dias feriados e dias santos, mas sempre sem perder de vista o convento, de onde o Superior os pudesse observar. Ao término de alguma das disciplinas escolares, terão todos os Colegiais um dia inteiro, ou uma tarde, de recreio no distrito da Ilha, mas sempre com acompanhamento do irmão Lente. Nenhum Colegial, Passante ou Leitor poderá pernoitar fora do convento. Os sacerdotes só poderão sair do convento ou ir à cidade uma vez por mês; e os coristas colegiais só poderão ir à cidade para visitar parentes em primeiro grau mortos ou gravemente enfermos e quando forem defender teses nas conclusões públicas. As férias deviam os estudantes passá-las no convento da Ilha, porém só com banca de estudo na parte da manhã, tendo a tarde livre; e nas festas de primeira classe eram dispensados também disso (39).

Se a compararmos com a de hoje, vemos que a disciplina daquele tempo não deixava muita folga aos estudantes, nem mesmo nas férias. Deviam os Colegiais dedicar-se muito sèriamente às suas obrigações de estudantes.

4). - As últimas prescrições da Lei Escolástica dirigem-se aos superiores dessa casa de estudos na Ilha do Bom Jesus. O Bispo insiste no dever de êles providenciarem todo o necessário para o sustento dos estudantes e de distribuir de tal maneira os ofícios caseiros, que 0 estudo não sofra detrimento. A linguagem de Dom Guadalupe mostra o grande empênho em favorecer ao máximo os estudos na Província:

(38). - TG. II, f. 51v. As "pinturas ou artefícios" parecem indicar que os estudantes enfeitavam as fôlhas da tese com desenho ou de qualquer outro modo. 


\begin{abstract}
"... Ordenamos que o Prelado distribua com tal prudência os ofícios do convento pelos Colegiais, que os não grave no tempo do estudo. E assim terão muito zêlo e vigilância em que os ofícios se façam com tal brevidade e a tais horas, que sempre lhes fique livre para estudar o mesmo tempo que aliás têm os outros desocupados... Advertimos a um e outro (Prelado e Leitor) que lhes tomaremos e falemos tomar muito estreita conta sôbre o aproveitamento dos discípulos e que lhes não há de valer a escusa de que tal ou tais sujeitos eram rudes e incapazes para o aproveitamento das ciências... Por onde tratem de os obrigar com todo o rigor a estudar... Como também certificamos e prometemos a todos os estudiosos de os premiar quanto fôr possível pelos meios da Religião... segundo merecer o seu aproveitamento nos estudos; contanto que sejam bem procedidos" (40).
\end{abstract}

Admirável o interêsse do Bispo do Rio de Janeiro em incentivar os estudos sacros, aliás coerente com o empênho por êle mostrado em elevar o nível de instrução de todo o seu clero durante os quinze anos que passou no govêrno da diocese do Rio de Janeino.

Quais as novidades e qual o alcance dessa Lei Escolástica promulgada pelo Reformador? Dom Guadalupe não trouxe modificações essenciais aos estudos na Província. De modo geral êstes continuavam como os Estatutos da Província e da Ordem os tinham estabelecido. Mas em tôda a Lei Escolástica se revela a grande preocupação de levar os coristas a um maior rendimento nos estudos.

Em certos pontos, a lei trazia mitigações; em outros apertava ainda mais. Aboliu a recitação das matinas à meia-noite, transferindo-as para as $9 \mathrm{~h}$. da noite. Abolindo o estudo noturno e modificando um pouco o horário, ganharam os estudantes mais tempo - e tempo contínuo - para o sono: em vez de cinco horas obtiveram seis horas de sono no verão (das $10 \mathrm{~h}$. às $4 \mathrm{~h}$.) e sete horas no inverno (das $10 \mathrm{~h}$. às $5 \mathrm{~h}$.). Também o tempo das au’as, quer na parte da manhã, quer na da tarde, foi reduzido de duas e meia horas para duas. As horas de estudo ficaram melhor distribuídas. Mas todos, quer Colegiais quer Passantes, foram obrigados a assistir a tôdas a Horas do Ofício divino.

Conservou o Reformador os feriados já existentes, mas determinou que no período das férias houvesse banca de estudo na parte da manhã, menos nas festas de primeira classe.

Encorajou Dom Guadalupe a realização das conclusões e aumentou o seu número convencido certamente de que o clima de emu-

(39). - TG. II, f. 51-52.

(40). - TG. II, f. 52 . 
lação que tais atos criava era propício a suscitar maior paixão pelos estudos. Recomendou um moderado fausto para dar caráter mais festivo a tais atos públicos. Permitiu que os Colegiais fôssem à cidade do Rio de Janeiro para defender teses, quando antes rem nas férias lhes era lícito deixar a Ilha do Bom Jesus. E por fim, estabeleceu que, exceto no curso então já começado, a Teologia durasse sempre três anos completos (41).

\section{b). - Providência de 4-12-1738.}

Como referimos acima, o Convento do Bom Jesus da Ilha fôra construído especialmente para ser casa de estudos. Além dos estudantes e Lentes não havia outros membros na comunidade, a não ser o guardião e os esmoleres necessários. Os estudantes coristas é mesmo os sacerdotes não podiam exercer outra ocupação, senão o estudo; igualmente os Lentes não podiam ter outro apostolado, porque deviam ocupar-se com os Colegiais. Portanto afora as esmolas recolhidas pelos esmoleres, não havia outra fonte de renda. E uma vez que a comunidade dessa casa de estudos não era pequena, a manutenção do Colégio do Bom Jesus da Ilha evidentemente não era fácil. Devia o Colégio ser sustentado também pelas outras casas, pois as esmolas não bastavam.

Urgia, portanto, tomar alguma providência para resolver também o problema da manutenção dessa casa de estudos. Foi o que o Reformador fêz, promulgando, pouco depois da Lei Escolástica de 10 de novembro, a Providência de 4 de dezembro de 1738 (42).

Esta Providência é um documento breve, em cinco parágrafos, que passamos a resumir:

1). - O guardião do convento possa encomendar a todos os sacerdotes da casa dez intenções de missas cada mês. E devido à dificuldade de obtê-las é o guardião do Convento de Santo Antônio do Rio de Janeiro exortado a socorrer o Colégio da Ilha com algumas intenções, quando as houver.

2). - Os Provinciais dêem ao convento da Ilha uma pipa de azeite cada ano, que poderá ser comprado com algumas esmolas da Província ou com o dinheiro obtido da distribuição dos hábitos aos conventos. Aconselha-se mandar vir o azeite de Portugal, "por ficar mais acomodado".

(41). - Cf. ROEWER, Os Estudos, p. 104-105.

(42). - TG. II, f. $52 \mathrm{v}-53$. 
3). - Seja dado ao convento da Ilha todo o lucro obtido com as folhinhas da Província que são vendidas caro embora custe pouco sua impressão em Lisboa (43) .

4). - O síndico do convento mande para as Minas Gerais os hábitos velhos dos frades, para distribuí-los como mortalhas e dêsse modo ajudar o convento com as esmolas obtidas (44).

5). - O Convento de Santo Antônio do Rio de Janeiro trate gratuitamente todos os religiosos enfermos do Convento do Bom Jesus, por todo o tempo em que êste fôr casa de estudos.

Foram estas as determinações do Bispo Dom Guadalupe, Reformador Apostólico da Província da Imaculada Conceição do Rio de Janeiro, referentes aos estudos na mesma. Por isso, não voltou mais ao assunto em sua grande Pastoral de Reforma, que examinaremos no Capítulo seguinte. Nessa Pastoral Dom Antônio de Guadalupe apenas se refere algumas vêzes à ignorância dos confessores e pregadores e estabelece algumas normas para as Conferências de Moral e Casos de Consciência, a fim de aprimorar-lhes a preparação para o ministério; mas não dá mais nenhuma determinação concreta relativa aos estudos.

Qual o a'cance das determinações do Reformador para o Colégio do Bom Jesus da Ilha? Trata-se sem dúvida de providência em si muito acertada. Evidentemente uma casa de estudos necessita da ajuda de tôda a Província para poder ser mantida. E a Lei Escolástica tornou muito mais razoável o horário do estudo, do repouso e das aulas.

Contudo, o funcionamento do Colégio da Ilha não durou muito tempo. Apenas acabado o triênio do Provincial Frei Lucas, colocado no cargo por Dom Antônio de Guadalupe, determinou o Capitão provincial de 7 de janeiro de 1742:

"que pelos grandes descômodos e inconvenientes, que se têm experimentado nos estudos que se abriram no Convento do Senhor Bom Jesus da Ilha, por serem os tais inconvenientes irreparáveis, se determina que se não torne a abrir estudos no dito convento da

(43). - Não conseguimos descobrir o que eram tais "folhinhas da Província". Talvez sejam os calendários litúrgicos.

(44) . - Era costume muito espalhado então. Pessoas piedosas desejavam ser enterradas revestidas do burel franciscano. Quando morriam, os familiares procuravam hábitos nas casas dos frades. Os hábitos velhos eram guardados para êsse fim. Podia-se aceitar esmola pelo burel dado, mas era severamente proibido vendê-lo às pcssoas interessadas. 
Ilha, e se continuem neste de Santo Antônio do Rio de Janeiro, como sempre se costumou" (45).

Quais seriam tais "inconvenientes e descômodos irreparáveis"? Não o dizem expressamente os Padres capitulares, mas certamente trata-se da dificuldade em prover a comunidade do sustento e do material escolar (46).

Com efeito, a Ilha do Bom Jesus era muito pequena. Em 1730 moravam neela só três habitantes, como atesta Frei Apolinário (47). Afora $o$ que se pudesse cultivar na horta, todo o resto para o sustento dos frades do Colégio devia ser arranjado na cidade e trazido para a Ilha. Os esmoleres e também outros frades do convento precisavam ir frequientemente à cidade. $\mathrm{E}$, como tudo dependia da oportunidade das embarcações, tornam-se evidentes os incômodos, não só para o sustento do Colégio, mas também para a disciplina regular.

Do ponto de vista do estudo, também apareciam inconvenientes. Como prover o Colégio da Ilha com o material necessário para um estudo eficiente? A grande biblioteca achava-se no Convento de Santo Antônio no Rio de Janeiro. Impossível seria transferíla para a Ilha; e muito difícil tornava-se sua consulta por parte dos estudantes e também dos professôres, que perderiam um tempo precioso demais para vir consultá-la.

Foi, pois, acertada a transferência dos estudos para o Convento de Santo Antônio, onde haviam funcionado já por tantos decênios. As providências do Reformador Dom Guadalupe, ajuizadas em si, não podiam eliminar os inconvenientes inerentes à própria situação do Convento do Bom Jesus da Ilha .

Além das duas medidas referentes aos estudos analisadas neste Capítulo, não consta nenhuma outra no Livro do Tombo. Sabe-se, porém, que Dom Antônio de Guadalupe incentivou os estudos de Gramática. Quem nô-lo assegura é o próprio Provincial Frei Lucas de São Francisco - o Superior colocado no cargo pelo Reformador ao estabelecer normas para o Convento de Cabo Frio, estando ali em visita canônica a 22 de setembro de 1739:

“... E como também o mesmo Senhor [Dom Antônio de Guàdalupe] com grande empênho e zêlo mandou estabelecer estudos de Gramática em tôda a Província para instruir os irmãos coristas, e a êste fim os isenta de todo o serviço braçal que lhes tome o tem-

(45). - TG. II, f. 61.

(46). - Cf. ROEWER, Páginas, p. 451.

(47). - CONCEIÇÃO, Epitome, § 14. 
po, mandamos que assim se cumpra, como se pratica em todos os mais conventos onde se estabeleceram os ditos estudos" (48).

Nada mais conseguimos apurar, a não ser esta referência aliás bastante vaga - de que o Reformador mandara estabelecer estudos de Gramática "em tôda a Província". Não cremos que dêle tenha emanado alguma determinação por escrito, pois em tal caso certamente o cuidadoso autor do Livro do Tombo da Província, Frei José do Destêrro, tê-la-ia conservado. Talvez tenha sido uma recomendação oral feita pelo Reformador. E' inverossímil que, caso tivesse Dom Antônio baixado alguma lei por escrito, se tenha esta perdido.

Não possuímos dados concretos para avaliarmos o cumprimento dêste desejo do Reformador de que se abrissem cursos de Gramática em tôda a Província. Como já expusemos acima, o curso de Gramática funcionou no Convento de São Boaventura em Macacu; e deve ter funcionado também no de Cabo Frio, provàvelmente já antes de 1739, pois Frei Manuel da Encarnação alegara um ano antes ter ali ensinado (49) .

Teriam sido abertos cursos de Gramática para coristas também em outros conventos, além dêstes dois? Nada a respeito encontramos nos documentos do Arquivo da Província, embora a determinação supra-mencionada de Frei Lucas de São Francisco para o Convento de Cabo Frio afirme:

"... mandamos que assim se cumpra, como se pratica em todos os mais conventos onde se estabeleceram os ditos estudos".

(Continua).

(48). - Tombo de Cabo Frio, f. $21 \mathrm{v}-22$.

(49). - TG. HI, f. $43 \mathrm{v}$. 